\title{
Leadership Styles of Headteachers and Their Impact on Students' Academic Performance in Secondary Schools, Nyamaiya Division, Nyamira District, Kenya
}

\author{
Mr. Evans Nyagaka \\ School of Humanities and Social Sciences \\ Jaramogi Oginga Odinga University of Science and Technology \\ P.O. Box 210 - 40601, Bondo, Kenya.

\section{Dr. Ajowi Jack Odongo} \\ School of Education \\ Jaramogi Oginga Odinga University of Science and Technology \\ P.O. Box 210 - 40601, Bondo, Keny
}

\section{Doi:10.5901/jesr.2013.v3n3p157}

\begin{abstract}
The nerve centre of this study was that despite the critical role played by the head teacher in secondary school management, students' academic performance has persistently been poor. Factors leading to this dismal performance have not been adequately investigated and well understood in Nyamaiya Division hence the need for this study. Therefore, the purpose of this study was to determine the leadership styles of the headteachers and their impact on the students' academic performance in KCSE secondary schools in Nyamaiya Division, Nyamira District. The study was conducted in six secondary schools within Nyamaiya Division, Nyamira District from population of 15 schools, hence six headteachers, and 72 teachers from population of 180 and 680 students from population of 1700. The interest of the researcher to choose and study these schools is strongly prompted by their continued poor performance in KCSE. Data was collected using the questionnaires and interview schedules. The study used descriptive statistics such as percentages and frequency, which were used concurrently with the Chi-Square test in the analysis. The study intended to come up with policy guidelines that were to help improve the leadership styles of head teachers in Kenya and other developing countries, which require similar policies. The study was further to contribute to the functions of knowledge for the present and future scholars. The major findings show a significant relationship between initiative structures of the head teachers towards improving leadership style which has impact on academic performance, it further shows no significant relationship between consideration behavior of the head teachers regarding day to day issues which has impact on academic performance and finally there was a strong relationship between participatory traits of the head teachers and the management structures of the schools which has impact on the students' academic performance. Based on these findings, it is recommended that to the school administration to cooperate from parents by holding regular meetings and working out strategic plans, to the ministry to in-service headteachers through workshops and finally to the teacher to be encouraged occasionally to review their own leadership styles and check their impact on students' academic performance.
\end{abstract}

Keywords: Head teacher Leadership Styles, Students' Academic Performance Administration.

\section{Introduction}

This chapter presented the background information, statement of the problem, purpose of the study, objectives of the study, hypotheses of the study, significance of the study, limitations of the study, basic assumptions, definition of significant terms, theoretical underpinnings, conceptual framework and organization of the study.

Kenyan's formal Education System has its roots in the activities of European missionaries at the onset of colonial rule. During this period, education was infused with British content, practice and ethos (Eshiwani, 1983). Further, the administration of the education system was along racial lines catering differently for three main races: Europeans, Asians and Africans, until 1960 when Asian and African children were admitted into European secondary schools for the first time. Despite the fact that the Africans constituted the majority of Kenya's population 97\% in 1953, their representation in education, particularly in post primary schooling, was very low (Gay, 1952).For example, at independence, there were only 30,121 secondary students enrolled in 151 secondary schools with only 1,602 teachers. Currently there are about 800,000 students in the country's 6,000 secondary schools (Daily Nation, Tuesday January 26, 2010).

The situation remained much the same at independence at a time when there was great need for indigenous 
skilled work force in various government ministries as well as in the private sector. In Kenya, differences are noticeable between government schools and those sponsored by individual communities as well as religious organizations.

Up to 2009, the ministry of Education had four categories of schools. Nineteen national schools-elite institutions take the best pupils from each district. Then there are provincial schools regarded as second best but often outshining the national schools (Haji 1985). These are used to serve an entire province, but now they take 85 percent of the students from the home district, and the balance from the rest of the province (quarter system). District schools admit students from their own catchments areas and generally include former community built schools, which have nowadays been classified as public ordinary schools. Finally, there are private schools that are not funded in any way by the government.

The system of education is highly selective even at the primary school level, while access to schooling is limited; advancement is mediocrity since it is solely based on student's performance in examinations. Examinations are used above all to identify and define those adjudged suitable to proceed to the next stage of education. The process, which examinations serve to monitor and govern, is that of socializing individuals into progressively higher knowledge.

The academic achievement of many educational institutions is influenced by the leadership styles of administration and management team (Tetty-Enyo, 1997). Olembo (1997) also concurs with Tetty-Enyo (1997), by observing that school leadership is the act of influencing the activities of the teachers and students in an effort to adhere to educational objectives within the school.

It is on this basis that the importance of leadership has become more pronounced today. The expansion of knowledge in the world has led to information technology (IT) and hence resulting in the formation of complex organizations, which require trained specialists in order to achieve the set objectives.

This explains why many researchers are interested in the field of leadership to test the various theories of leadership and build new ideas to improve on the effectiveness and success of various organizations. Campbell. (1974) indicates that the secondary school head teachers are charged with the responsibility of running schools by addressing themselves to six major administrative tasks: Curriculum and instructional task, School community relationship task, Finance and business administrative task, Staff personnel task, Pupil personnel task and School plant task.

Hoy and Miskeel (1992), concurs with Campbell and adds by saying that at the building level, the head teacher is usually the key figure in fostering shared governance within the school. Head teachers not only have increased responsibility and authority in school programmed curriculum and personnel decisions, but also increased accountability for a student and program success.

In reference to the advanced technological and social advancement in the country, (Olembo, 1997), observed that national and individual citizen's expectations from the educational system are greater and more complicated. It requires a highly qualified head teacher to implement the curriculum that adheres to national objectives and individual demands. Introduction of software technology, banning of corporal punishment, changes in curriculum requires a highly qualified head teacher in order to be able to coordinate all the efforts of the people concerned to work towards the attainment of the set objectives.

There are several definitions given by different scholars on the concept of leadership. According to Muya (1993), leadership is the lifting of a man's vision to higher sights, the raising of man's performance to higher standard, the building of man's responsibility beyond its normal limitations. Halpin (1969) looks at leadership as consisting of two aspects namely a group achievement and group maintenance. This involves the directing of the group towards the achievement of the organizational goals. It also implies the sustenance of the social relationships at work.

McGregor (1960) maintains that leadership over human beings is exercised when persons with certain motives and purposes mobilize, in competition or conflict with others, institutional, political, psychological and other resources so as to rouse, engage and satisfy the motives of followers. Burns (1978), concludes leadership, unlike naked power welding is thus inseparable from followers' needs and goals.

Sergiovanni et al (1987) authors of the bestseller in search of excellence, describe Leadership in action terms. They say that leadership is many things. It is patient, usually boring coalition building. It is purposeful seeding cabals that one hope will result in the appropriate ferment in the bowels of the organization. It is meticulously shifting the attention of institution through the mundane language of management systems. It is altering agenda so that new priorities get enough attention. It is being visible when things are going awry and invisible when they are working well. It is building a loyal team at the top that speaks more or less with one voice. It is listening carefully much of the time frequently speaking with encouragement and reinforcing words with believable action. It is being tough when necessary.

Leadership is the ability to develop a vision that motivates others to move with a passion. Leadership is seen as the process of encouraging and helping others to work enthusiastically towards objectives. The human factor builds a group together and motivates it towards goals by transforming the group's potential into realities. 
Cole (1997) defines leadership as a dynamic process at work in a group whereby one individual over a particular period of time, and in a particular organizational context influences the group members to commit themselves freely to the achievement of group tasks or goals. He continues to say that leadership development must be a value and a process that evolves within the institution over a period of five to ten years.

Manu (2007) also defines leadership as the ability to get a man to do what you want him to do when you want it done, in a way you want it done, because he wants to do it.

The desire to excel has been there since the formal education was introduced in Kenya at the time of Africa's quest to obtain education like that of Europeans that made them pursue it with a great interest. This called upon the need for good management and leadership style. Good performance in school is relatively equivalent to good administration. Raju (1973) emphasizes that the administrative role of the head teacher involves directing, controlling and management of all matters pertaining to education enhancement in the school. This implies that all the activities done in the school are performed on behalf of the head teacher.

Eshiwani (1983) identifies that schools which consistently perform well tend to have sound and efficient leadership. He further stresses that leadership is a crucial factor in the success of a school. The qualities that are expected of a school head teacher include setting a climate of high expectations for staff and students, encouraging collegial and collaborative leadership and building commitment.

According to Mwaoria (1993), the main tasks of the school head teacher are to interpret national policies, executing curriculum program, seeing to students' welfare, equipping physical facilities and finances, inducting and retaining school community relations. In other words, if the school fails in performance of examinations the head teacher has failed.

While poor performance is applicable, to most parts of the country other areas have a record of perennial mass failures in national examinations. This is especially so in Nyanza province where students have continued to perform poorly not only in KCSE but also in KCPE.

Table 1.1. The Mean Score for KCSE Results in Nyamira District Between $2004-2008$

\begin{tabular}{|c|c|c|c|c|c|c|}
\hline Code & District/Year & $\mathbf{2 0 0 4}$ & $\mathbf{2 0 0 5}$ & $\mathbf{2 0 0 6}$ & $\mathbf{2 0 0 7}$ & $\mathbf{2 0 0 8}$ \\
\hline 701 & Kisumu & 5.5801 & 5.4327 & 5.3003 & 5.2459 & 5.2507 \\
\hline 702 & Kisii & 4.3521 & 4.4831 & 4.2089 & 4.3618 & 4.3909 \\
\hline 703 & Homa Bay & 5.6842 & 5.6842 & 5.3841 & 5.58 & 5.6234 \\
\hline 704 & Siaya & 5.8715 & 5.7732 & 5.5232 & 5.6284 & 5.8742 \\
\hline 705 & Nyamira & 4.3914 & 4.277 & 3.9773 & $\mathbf{4 . 0 8 7 2}$ & $\mathbf{4 . 1 5 9 9}$ \\
\hline 706 & Migori & 5.826 & 5.6203 & 5.4706 & 5.8883 & 6.1127 \\
\hline 707 & Kuria & 4.9213 & 4.8239 & 4.6495 & 4.8449 & 5.2173 \\
\hline 708 & Suba & 4.7912 & 5.7273 & 5.7014 & 6.0137 & 6.0463 \\
\hline 709 & Rachuonyo & 5.5616 & 5.3725 & 5.001 & 5.4007 & 5.4401 \\
\hline 710 & Gucha & 4.5459 & 4.5001 & 4.2147 & 4.0773 & 4.3159 \\
\hline 711 & Bondo & 6.005 & 5.9357 & 5.6984 & 5.9725 & 6.1116 \\
\hline 712 & Nyando & 6.0246 & 5.6259 & 5.4153 & 5.8165 & 5.8458 \\
\hline
\end{tabular}

Source: KNEC 2008

Compared to the national average mean score of seven, the mean score for Nyamira District has been low. For example, over the years, the district has continued to perform poorly in national examinations compared to other districts and its contribution in the education sector is very minimal. The bulk of students in Nyamira District do not qualify for admission even to teacher training colleges since the mean entry requirement has been raised from mean grade $D$ (plus) to $C$ (plain), (MoEST circular of 2008). The district has failed to narrow the differences in KCSE mean scores between it and the leading district in any year and as consistently remained the last or second last in terms of overall performance, in Table 1.1.

The poor performance in national examinations has persisted for a long time and most stakeholders in the district including parents, teachers and education officers are looking for answers to explain the state of affairs.

Several incidents have been reported in the media whereby head teachers of secondary schools have been chased from their stations of work by angry parents and students due to poor academic performance. For example in an article (Daily Nation March 24, 2004), Students Bid to Burn School is thwarted. Students from Nyaisa Secondary School claimed that the school had been doing poorly in national examinations because its management had not addressed the 
problem of shortage of teachers.

In another incident reported in the media (Kenya Times, May 19, 2005) 'Angry Parents Storm Schools.' Angry parents locked out a secondary school head teacher in Nyamira District for allegedly running down the institution.

The parents locked the administration block of Bomoriito secondary school and removed their children from classes, accusing the head teacher of absenteeism and posting poor performance since he was posted to the school some four years ago.

It is evident from the above incidences that there is a great controversy as to who is responsible for the persistent poor academic performance in KCSE examinations in Nyamira District. Parents and other stakeholders solely blame the head teachers of the schools for being unable to deliver.

Statistics by KNEC (2008) show that, Nyamira district is always at the bottom of the rank. Nyamira's mean score since 2004 has consistently been below the national average of seven. This naturally worries parents, leaders and scholars from the district causing them to wonder about the cause of this poor performance.

In an examination oriented education system, like Kenya's failure in examinations may well mean failure in life. Low performance in KCSE in any district will definitely affect the development of that area as well as national development as a whole. Thus the issues responsible for the poor performance in examinations deserved to be investigated.

Based on the problem stated above, the purpose of this study was to analyze the leadership styles of the head teachers and their impact on the students' academic performance in secondary schools in Nyamaiya Division, Nyamira Distri

This study had the following specific objectives:-

i. To assess the leadership style of initiative structure of the head teachers on the students' academic performance.

ii. To assess the leadership style of consideration structure of the head teachers on the student's academic performance.

iii. To assess the leadership style of participatory structure of the head teachers on students' academic performance.

\section{Hypotheses}

- $\mathrm{HO}_{1}$-There is no significant relationship between initiative structure of the headteachers and students' academic performance.

- $\mathrm{HO}_{2}$-There is no significant relationship between consideration structure of the headteachers and students' academic performance.

- $\mathrm{HO}_{3}$-There is no significant relationship between participatory structure of the headteachers and students' academic performance.

\section{Research Methodology}

This was an exploratory study that was to use a descriptive survey design to investigate the leadership styles of the head teacher and their impact on the students' academic performance. Descriptive survey designs are used in preliminary and exploratory studies to allow researchers to gather information, summarize, present and interpret for the purpose of clarification (Orodho, 2002).

Borg and Gall (1989), noted that descriptive survey research is intended to produce statistical information about aspects of education that interest policy makers and educators. By involving a broad category of head teachers, teachers and students the proposed study is within the cross-sectional sub-types of descriptive survey study designs.

Therefore, through descriptive survey, the researcher intended to determine the nature and the extent of this performance. That was to determine the status without manipulating the variables. The target population for this study consisted of all the head teachers, teachers and students of all the secondary schools in Nyamaiya Division. Specifically all the 15 head teachers, 180 secondary school teachers and 1700 students.

Schools were selected across categories and school types. The following stratified and random sampling procedure was used to select the study schools. 
Table 3.1. Sampling Matrix for schools

\begin{tabular}{|c|c|c|c|c|c|c|c|c|c|c|c|c|c|c|c|c|c|c|c|c|c|}
\hline Type/Gender & \multicolumn{6}{|c|}{ Girls } & \multicolumn{6}{|c|}{ Boys } & \multicolumn{9}{|c|}{ Mixed } \\
\hline & \multicolumn{3}{|c|}{ Provincial } & \multicolumn{3}{|c|}{ District } & \multicolumn{3}{|c|}{ Provincial } & \multicolumn{3}{|c|}{ District } & \multicolumn{3}{|c|}{ Provincial } & \multicolumn{3}{|c|}{ District } & \multicolumn{3}{|c|}{ Private } \\
\hline & $\mathrm{N}$ & $\mathrm{N}$ & $\%$ & $\mathrm{~N}$ & $\mathrm{~N}$ & $\%$ & $\mathrm{~N}$ & $\mathrm{~N}$ & $\%$ & $\mathrm{~N}$ & $n$ & $\%$ & $\mathrm{~N}$ & $n$ & $\%$ & $\mathrm{~N}$ & $n$ & $\%$ & $\mathrm{~N}$ & $n$ & $\%$ \\
\hline Day & - & - & - & - & - & - & - & - & - & - & - & - & - & - & - & 9 & 2 & 22.2 & - & - & - \\
\hline Boarding & 1 & 1 & 100 & - & - & - & 1 & 1 & 100 & - & - & - & - & - & - & - & - & - & - & - & - \\
\hline $\begin{array}{c}\text { Both day and } \\
\text { Boarding }\end{array}$ & - & - & - & - & - & - & - & - & - & - & - & - & - & - & - & 3 & 1 & 33.3 & 1 & 1 & 100 \\
\hline
\end{tabular}

Key: $\mathrm{N}=$ Target Population, $\mathrm{n}=$ Sample, $\%=$ Percentage

For the case of this study, a sample of six secondary schools was purposively selected from 15 secondary schools, 72 secondary teachers from a population of 180 secondary teachers and 680 secondary students from a population of 1700 students were purposively selected. This was gave a sample size of $40 \%$. The researcher used purposive sampling of category of schools by hand picking two day schools, two boarding schools and two day and boarding schools were selected. Random sampling was used to select the teachers and students to be involved in the study.

Data concerning the influence of the leadership style of a secondary school head teacher on achieving high academic performance was obtained by use of two questionnaires, one for the head teachers and the other for teachers. The questionnaires had six parts: part one was on the preamble, part two was on the background information of the respondent, part three was on the initiative structure, part four was on the consideration structure, part five was on the participatory structure and art six was on school facilities that influence academic performance.

These questionnaires contained both open ended questions and close ended questions. Open-ended questionnaires give the respondent an opportunity to express their views, experiences and suggestions fully. The closed ended questionnaires are easier to code responses and analyse them by use of computer. The researcher used interview schedules to interview teachers and head teachers in all the secondary schools. The researcher's selection of interview schedules as one of the research instruments is influenced by Kerlinger (1973), who observed that more people are willing to communicate orally than in writing and will therefore provide data more readily in an interview. This justified the use of interview schedules in the study. The researcher was able to probe the participants and gave explanations and clarification where necessary as regard the problem under study. Prior to the main study, a pilot study was carried out. One district school was picked using the blind folding technique from the sampled three schools for the purpose of piloting the instruments.

Content validity, measures the degree to which the test items represent the domain or universe of the trait or property being measured (Wallace, 2009). In order to establish the content validity of a measuring instrument, the researcher must identify the overall content to be represented. Items must then be randomly chosen from this content that will accurately represent the information in all areas. By using this method the researcher should obtain a group of items which is representative of the content of the trait or property to be measured.

The term construct validity is defined as a property that is offered to explain some aspect of human behavior, such as mechanical ability, intelligence, or introversion The construct validity approach concerns the degree to which the test measures the construct it was designed to measure.Criterion-related validity is concerned with detecting the presence or absence of one or more criteria considered to represent traits or constructs of interest. One of the easiest ways to test for criterion-related validity is to administer the instrument to a group that is known to exhibit the trait to be measured.

The reliability of a research instrument concerns the extent to which the instrument yields the same results on repeated trials. Although unreliability is always present to a certain extent, there was generally be a good deal of consistency in the results of a quality instrument gathered at different times. The tendency toward consistency found in repeated measurements is referred to as reliability. The questionnaires were given to the respondents to fill in the presence of the researcher in order to see if they were experiencing any problem in filling them. The researcher was able to probe the participants and gave explanations and clarification where necessary as regards the problem under the study. To compute the correlation coefficient of the instruments, the following formula was used.

$$
R=\frac{\sum X Y-\left(\sum X\right)\left(\sum Y\right)}{N}
$$

The researcher was given a research permit from the district education office and an introductory letter from the school of educational management policy and curriculum studies, Kenyatta University. The researcher delivered all questionnaires to the schools personally. During this personal contact, the researcher will explain some of the complex aspects of the questionnaire. 
The respondents will be given two weeks to fill the questionnaires and the researcher will collect them. There will be an allowance of two weeks for those who had not filled the questionnaires. The KCSE results of the sampled schools will be collected from the District Education Office for the years 2004, 2005, 2006, 2007 and 2008.

The hypotheses for the study were tested using the Statistical Package for Social Science (SPSS).The statistical analysis was to establish whether a significant relationship exists between the mean scores of the head teacher based on the initiative structure, consideration structure, participatory management structure, educational qualification, and the category status of the school. The 0.05 level of significance was used as the standard for rejecting or accepting the null hypotheses. Descriptive statistics such as percentages and frequency were used concurrently in the analysis and ChiSquare test. The results obtained gave the researcher the basis for making inferences in testing the formulated hypotheses for the study.

\section{Results and Discussions}

\subsection{Introduction}

This study was conducted to analyze the leadership styles of the head teachers and their impact on the students' academic performance in secondary schools in Nyamaiya Division, Nyamira District.

The sample involved six out of 15 secondary school head teachers and 72 secondary school teachers from a population of 180 secondary school teachers in Nyamaiya Division, Nyamira District. Data were collected from the sampled population using questionnaires. It was analyzed using Statistical Package for Social Sciences (SPSS version 17.0) computer package as it is one of the latest versions of statistical analysis software. The research findings were presented in graphs, tables and figures as appropriate, as well as narrations. The study sampled six head teachers and 72 teachers in secondary schools both male and female in Nyamaiya Division, Nyamira District which had $88.5 \%$ ( $n=69$ ) of the sampled population as male and $11.5 \%(n=9)$ being female. In this study there were more male respondents than their female counterparts as shown in 4.1.

Figure 4.1. Gender of the Respondents

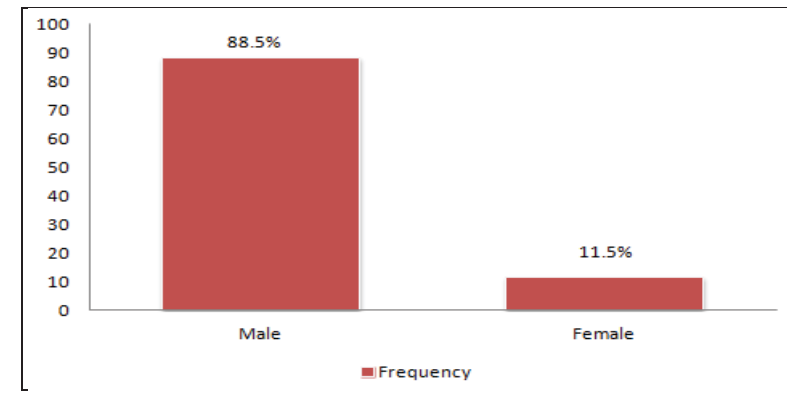

\subsection{Age Distribution of the Respondents}

The respondents who participated in this study were found to be in the following age brackets. The age distributions between $21-30$ years were $29.5 \%$ while those respondents aged between $31-40$ years were $51.3 \%$ and those aged between $41-50$ years being $15.4 \%$ while those 51 and above years being $3.8 \%$ as shown in 4.1 .

Table 4.1. Age Distribution of the Respondents in Nyamira District

\begin{tabular}{lll}
\hline Age Distribution & Frequency & Percentage \\
\hline $21-30$ Years & 23 & 29.5 \\
$31-40$ Years & 40 & 51.3 \\
41-50 Years & 12 & 15.4 \\
51 Years and Above & 3 & 3.8 \\
\hline Total & $\mathbf{7 8}$ & $\mathbf{1 0 0}$ \\
\hline & $\bullet \bullet \bullet$ &
\end{tabular}




\subsection{Academic Qualification of the Teachers}

In this study, $15.4 \%(n=12)$ of the respondents had Diploma level of education, $2.6 \%(n=2)$ had Bachelor of Arts/Bachelor of Science with post graduate Diploma in education, $69.2 \%(n=54)$ had Bachelor of education degree, while 10.2\% ( $n=8)$ had Masters Degree even though 2.6\% $(n=2)$ had other qualifications. From these findings, it showed that majority of the respondents' were qualified teachers as $82.0 \%$ of the sampled teachers had Bachelor of education Degrees and above. From these findings we can deduce that the information received from these respondents was credible to help the researcher analyze the leadership styles of the head teachers and their impact on the students' academic performance in secondary schools in Nyamaiya Division, Nyamira District. The Table 4.2 shows these findings:

Table 4.2. Academic Qualification of Teachers/Head Teachers

\begin{tabular}{lll}
\hline Academic Qualification & Frequency & Percentage \\
\hline Diploma Level & 12 & 15.4 \\
BA/BSC with PGDE & 2 & 2.6 \\
BED & 54 & 69.2 \\
Masters & 8 & 10.2 \\
Any Other & 2 & 2.6 \\
\hline Total & $\mathbf{7 8}$ & $\mathbf{1 0 0}$ \\
\hline
\end{tabular}

\subsection{The Category of School}

In this study the researcher sort information from different category of schools ranging from boys boarding schools, girls boarding schools, mixed day schools and mixed \& boarding public and private secondary schools in Nyamaiya Division, Nyamira District. The frequency and percentage of the findings were as indicated in the table below:

Table 4.3. Category of Secondary Schools Interviewed

\begin{tabular}{|l|r|r|}
\hline Secondary Schools & Frequency & Percentage \\
\hline Day & 2 & 33.3 \\
Boarding & 2 & 33.3 \\
Day and Boarding & 2 & 33.3 \\
Total & $\mathbf{6}$ & $\mathbf{1 0 0 . 0}$ \\
\hline
\end{tabular}

\subsection{Years of Experience of the Head Teachers}

The findings of the study showed head teachers who taught for $2-5$ years were $50.0 \%$ while those who taught for between $6-10$ years were $33.33 \%$ and between $11-15$ years $16.7 \%$. This shows that most head teachers have a lot of experience in as head teachers. Figure 4.2 shows the distribution of the head teachers regarding the number of years they had as head teachers.

Figure 4.2. Years of Experience of the Head Teachers

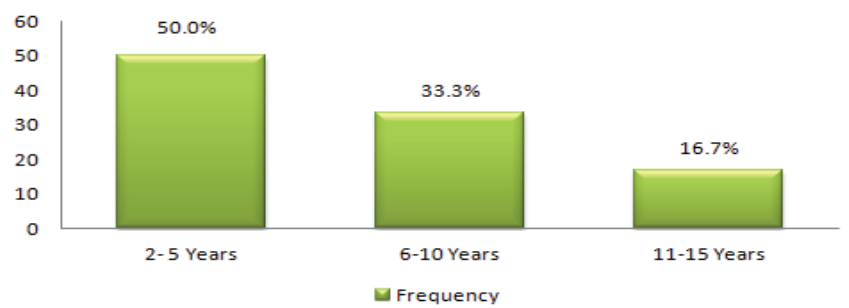

The researcher sought information from the head teachers from all types of schools including all girls' school, all boys' school and mixed schools. 


\subsection{Initiative Structure}

The researcher in this study interrogated the initiative structures undertaken by both the teachers and head teachers towards improving the leadership styles by posing some questions to establish their feelings towards the same and the frequencies of their responses were computed in terms of whether they Always, Often, Occasionally, Rarely or never act on issues questioned below. The responses were as shown in the table below;

Table 4.4. Initiative Structures from the Teachers Perspective.

\begin{tabular}{|c|c|c|c|c|c|c|}
\hline Questions & Always & Often & Occasionally & Rarely & Never & $\chi^{2}$ \\
\hline Q1 & 4 & 20 & 35 & 9 & 4 & 27.03 \\
\hline Q2 & 4 & 10 & 31 & 20 & 7 & 19.33 \\
\hline Q3 & 2 & 15 & 24 & 22 & 9 & 13.69 \\
\hline Q4 & 11 & 17 & 20 & 11 & 7 & 4.28 \\
\hline Q5 & 2 & 15 & 30 & 20 & 5 & 18.82 \\
\hline Q6 & 2 & 17 & 18 & 22 & 13 & 9.08 \\
\hline Q7 & 11 & 20 & 24 & 13 & 4 & 9.60 \\
\hline Q8 & 6 & 9 & 17 & 25 & 15 & 9.08 \\
\hline Q9 & 7 & 16 & 28 & 11 & 7 & 11.21 \\
\hline
\end{tabular}

Note:

Q1- Head teacher makes his or her attitudes clear to the staff

Q2- Head teacher maintains definite standards of performance

Q3- Head teacher lets staff members know what is expected of them

Q4- Head teacher rules out with an iron hand

Q5- Head teacher sees to it that the work of staff members is coordinated

Q6- Head teacher emphasizes the meeting of deadlines

Q7- Head teacher works without schedules

Q8- Head Teacher criticizes poor work

Q9- Head teacher seeks new and better ways

Note:

$x^{2}=$ Chi- Square, $\quad{ }^{\star *} p<0.05$ ( $p$ value) for all the questions.

The study established that most head teachers would more often or occasionally make their attitudes clear to the staff, thereby maintaining definite standards of performance as supported by the distributions of responses to questions 1 and 2. According to the findings of this study, head teachers more often and occasionally know what is expected of them although the chi-square test showed that there was no statistical significance to the fact that the head teachers rule with iron hand as the results showed a very low chi-square value of (4.28 and $p$ value of 0.370 ) which is $>0.05$, as supported by the distribution of responses to question 3 and 4 . Also, as revealed by significant distribution of responses to question 5 and 6, was that head teachers occasionally or more often than not saw to it that the work of members were coordinated and as well emphasized on meeting deadline.

In this study, the researcher requested for the opinion of the teachers in question 7 and 8 whether the head teachers worked without schedule and criticized poor work. The finding revealed that there was no statistical significance on whether the head teachers criticized poor work as the result showed ( $p$ value of 0.059 ) which above the 0.05 however they sought for new and better ways.

Table 4.5. Initiative Structures from the Head Teachers Perspective

\begin{tabular}{lcllll}
\hline Questions & Always & Often & Occasionally & Rarely & Never \\
\hline Q1 & 4 & - & 1 & 1 & - \\
Q2 & 4 & 1 & 1 & - & - \\
Q3 & 5 & 1 & - & - & - \\
Q4 & - & - & - & 1 & 5 \\
Q5 & 3 & 2 & 1 & - & - \\
Q6 & 3 & 2 & 1 & - & - \\
Q7 & - & 1 & - & 1 & 4 \\
Q8 & 2 & - & 2 & 1 & 1 \\
Q9 & 4 & - & - & 1 & 1 \\
\hline
\end{tabular}

Note:

Q1- Head teacher makes his or her attitudes clear to the staff 
Q2- Head teacher maintains definite standards of performance

Q3- Head teacher lets staff members know what is expected of them

Q4- Head teacher rules out with an iron hand

Q5- Head teacher sees to it that the work of staff members is coordinated

Q6- Head teacher emphasizes the meeting of deadlines

Q7- Head teacher works without schedules

Q8- Head Teacher criticizes poor work

Q9- Head teacher seeks new and better ways

The researcher established that the head teachers always made their attitudes clear to the staff members always maintains definite standards of performance as they often lets staff members know what is expected of them. The head teachers according to this study never rule out with an iron hand and always saw to it that the work of staff members is coordinated. They more often than not emphasized on the meeting of deadlines as well as criticize poor work. The study finally showed the head teachers sought for new and better ways.

The researcher hypothesized that there is no significant relationship between initiative structure of the head teachers and the students' academic performance but the findings shows different responses from the head teachers. From teachers perspective, the findings shows a significant relationship between initiative structures of the head teachers towards improving leadership style which has impact on academic performance as presented by slightly high chi-square results in the table 4.4 therefore the null hypothesis was rejected. This finding therefore fulfills the weaknesses of the Stogdill (1957), studies which did not have any satisfactory definition of leadership; they did not think that leadership is synonymous with good leadership; they failed to establish the role of the leader's initiating structure and consideration structure on the students' academic performance.

\subsection{Consideration Structure}

From this study the researcher wanted to know the consideration behaviour of teachers regarding day to day issues in the schools. The display of these responses was arranged coherently to permit careful comparison, detection of differences, noting patterns and seeing trends as well as establishing coherence of views. The frequencies of their responses were computed in terms of whether they Always, Often, Occasionally, Rarely or Never act on issues questioned below. The responses were as shown in the table 4.6.

Table 4.6. Consideration Structures From the Teachers Perspective.

\begin{tabular}{lllllll}
\hline Questions & Always & Often & Occasionally & Rarely & Never & $\chi 2$ \\
\hline Q1 & 7 & 20 & 31 & 13 & - & 9.72 \\
Q2 & 2 & 9 & 22 & 26 & 4 & 18.05 \\
Q3 & 11 & 13 & 24 & 13 & 9 & 5.15 \\
Q4 & 7 & 15 & 14 & 24 & 12 & 6.51 \\
Q5 & 9 & 16 & 24 & 9 & 12 & 5.74 \\
Q6 & 17 & 22 & 24 & 5 & 4 & 13.17 \\
Q7 & 6 & 16 & 15 & 14 & 21 & 3.44 \\
Q8 & 11 & 18 & 22 & 15 & 4 & 7.78 \\
Q9 & 15 & 22 & 13 & 15 & 7 & 4.21 \\
Q10 & 11 & 18 & 18 & 11 & 13 & 2.15 \\
Q11 & 5 & 28 & 17 & 20 & 2 & 17.02 \\
\hline
\end{tabular}

Note:

$x^{2}=$ Chi- Square, $\quad{ }^{* \star} p<0.05$ ( $p$ value) for all the questions.

Note:

Q1- Head teacher looks out for the personal welfare of members

Q2- Head teacher does little things to make it pleasant to be a member of staff

Q3- Head teacher does personal forums for staff members

Q4- Head teacher keeps to himself

Q5- Head teacher refuses to explain his/her actions

Q6- Head teacher is friendly and approachable

Q7- Head teacher treats all staff members as his equals

Q8- Head teacher is willing to make changes

Q9- Head teacher makes all staff members to feel at ease when talking to them

Q10- Head teacher is slow to accept new ideas

Q11- Head teacher is free, supportive and have respect for differences 
From this study it was observed that the head teachers occasionally look out for the personal welfare of even though most respondents observed that the head teachers does little things to make it pleasant to be a member of staff as can be evidenced on the responses to questions 1 and 2. The study further showed varied responses as to whether head teachers did personal forums for staff members, keep issues to themselves or refuses to their actions. There was no statistical significance to the responses to questions 3,4 and 5 as the chi-square test revealed a very low figure of less than 9.0 and probability $p$ value of above 0.05 . The findings showed that the head teachers were friendly and approachable as can be noted on response to question 6 . There was no coherence as to whether the head teachers treat all staff members as equal, their willingness to make changes or whether head teachers make all staff members to feel at ease when talking to them or slow to accept new ideas as can be noted on the responses to questions 7, 8, 9 and 10 respectively. The study however revealed that most head teachers were more often than not free, supportive and have respect for differences as can be evidenced in the responses to question 11 with a chi-square value of 17.02 and $p$ value of 0.002 which less than 0.05 , hence statistically significant.

Table 4.7. Consideration Structures from the Head Teachers Perspective

\begin{tabular}{llllll}
\hline Questions & Always & Often & Occasionally & Rarely & Never \\
\hline Q1 & 5 & 1 & - & - & - \\
Q2 & 3 & 1 & - & 1 & 1 \\
Q3 & 2 & - & 2 & - & - \\
Q4 & - & - & - & 3 & 3 \\
Q5 & - & - & - & 2 & 3 \\
Q6 & 6 & - & - & - & - \\
Q7 & 6 & - & - & - & - \\
Q8 & 6 & 1 & - & - & - \\
Q9 & 5 & - & - & 2 & - \\
Q10 & 3 & 6 & - & - & - \\
Q11 & 6 & &
\end{tabular}

Note:

Q1- Head teacher looks out for the personal welfare of members

Q2- Head teacher does little things to make it pleasant to be a member of staff

Q3- Head teacher does personal forums for staff members

Q4- Head teacher keeps to himself

Q5- Head teacher refuses to explain his/her actions

Q6- Head teacher is friendly and approachable

Q7- Head teacher treats all staff members as his equals

Q8- Head teacher is willing to make changes

Q9- Head teacher makes all staff members to feel at ease when talking to them

Q10- Head teacher is slow to accept new ideas

Q11- Head teacher is free, supportive and have respect for differences

The researcher established that the head teachers look out for the personal welfare of members, always did little things to make it pleasant to be a member of staff is expected of them. The head teachers according to this study never keep to themselves and refuse to explain his/her actions but always friendly and approachable. They always treated all staff members as their equals and willing to make changes. The study finally showed that the head teachers made all staff members to feel at ease when talking to them and were rarely slow to accept new ideas. The responses showed that head teachers were always free, supportive and have respect for differences.

In terms of consideration structures, the researcher hypothesized that there is no significant relationship between consideration structures of the head teachers and the student academic performance. From teachers perspective, the findings shows no significant relationship between consideration behavior of the head teachers regarding day to day issues which has impact on academic performance as presented by low high chi-square results in table 4.6 therefore the null hypothesis was accepted. Barrow (1976), indicated that low performing sub-ordinates caused the leader to behave much more punitively, more autocratically, less considerably and to push for more production, whereas high performance from the sub-ordinates resulted in the leader being more considerate towards the workers, less punitive, less autocratic and somewhat less task emphasis oriented. This finding also negates finding by Barrow (1976) who found that being considerate towards workers has significant relationship with the performance. 


\subsection{Participatory Management Structure}

From this study the researcher wanted to know the participatory traits of teachers on the management structures of schools. The display of these responses was arranged coherently to noting patterns and seeing trends of views. The frequencies of their responses were computed in terms of whether they Always, Often, Occasionally, Rarely or never act on issues questioned below. The responses were as shown in the table below;

Table 4.8. Participatory Traits From the Teachers Perspective.

\begin{tabular}{lllllll}
\hline Questions & Always & Often & Occasionally & Rarely & Never & $\chi 2$ \\
\hline Q1 & 18 & 24 & 28 & 2 & - & 11.77 \\
Q2 & 22 & 33 & 6 & 9 & 2 & 10.95 \\
Q3 & 9 & 16 & 22 & 22 & 2 & 7.03 \\
Q4 & 6 & 13 & 22 & 20 & 11 & 15.75 \\
Q5 & 4 & 12 & 26 & 25 & 5 & 20.62 \\
Q6 & 3 & 11 & 28 & 25 & 4 & 16.26 \\
Q7 & 8 & 17 & 31 & 7 & 7 & 15.74 \\
Q8 & 6 & 19 & 19 & 18 & 8 & 8.06 \\
\hline
\end{tabular}

Note:

$x^{2}=$ Chi- Square,$\quad{ }^{\star \star} p<0.05$ ( $p$ value) for all the questions.

Note:

Q1- Head teacher lets staff members know what is expected of them

Q2- Head teacher assigns staff member's particular tasks

Q3- Head teacher makes that all members understand them

Q4- Head teacher gets staff approval in important matters before implementing them

Q5- Head teacher puts suggestions met by the staff into operations

Q6- Head teacher lets group members diagnose group problems

Q7- Head teacher gives encouragement, support and appreciation to group members

Q8- Head teacher makes every member enjoy working with the others in the group

Q9- Head teacher mobilizes and utilize the potential resources and creativity of members for accomplishing group goals.

From this study it was observed that the head teachers occasionally let staff members know what is expected of them even though most respondents observed that the head teachers assign staff member's particular tasks as can be evidenced on the responses to questions 1 and 2. The study further showed that the head teachers both occasionally and rarely make that all members understand them in equal measure response to question 3 . The head teachers rarely or occasionally get staff approval in important matters before implementing them and as well rarely mobilizes and utilize the potential resources and creativity of members for accomplishing group goals even though there was no statistical significance to the responses to questions 4 and 9 as the chi-square test revealed a very low figure of less 7.03 and 8.05 respectively and probability $p$ values of above 0.05 in both responses to question 4 and 9 . The findings showed that the head teachers occasionally put suggestions met by the staff into operations and let group members diagnose group problems as can be noted on responses to question 5 and 6 . The head teachers occasionally give encouragement, support and appreciation to group members and as well as make every member enjoy working with the others in the group as was noted in the responses to questions numbers 7 and 8 respectively. From these findings, the researcher deduced that the head teachers perfected the participatory traits in their management styles.

Table 4.9. Participatory Traits from the Head Teachers Perspective

\begin{tabular}{llllll}
\hline Questions & Always & Often & Occasionally & Rarely & Never \\
\hline Q1 & 5 & 1 & - & - & - \\
Q2 & 5 & 1 & - & - & - \\
Q3 & 4 & 2 & - & - & - \\
Q4 & 5 & 1 & - & - & - \\
Q5 & 4 & 2 & - & - & - \\
Q6 & 4 & 1 & - & - & - \\
Q7 & 5 & 1 & - & - & - \\
Q8 & 5 & 1 & - & - & - \\
Q9 & 5 & 1 & - & - & - \\
\hline
\end{tabular}

Note:

Q1- Head Teacher lets staff members know what is expected of them 
Q2- Head teacher assigns staff member's particular tasks

Q3- Head teacher makes that all members understand them

Q4- Head teacher gets staff approval in important matters before implementing them

Q5- Head teacher puts suggestions met by the staff into operations

Q6- Head teacher lets group members diagnose group problems

Q7- Head teacher gives encouragement, support and appreciation to group members

Q8- Head teacher makes every member enjoy working with the others in the group

Q9- Head teacher mobilizes and utilize the potential resources and creativity of members for accomplishing group goals

The researcher established that the head teachers always let staff members know what is expected of them, always assigns staff member's particular tasks and all members understand them. According to the head teachers the staff members get staff approval in important matters before implementing them and to always put suggestions met by the staff into operations. Head teachers as evidenced in all the responses mobilize and utilize the potential resources and creativity of members for accomplishing group goals.

In terms of participatory management, the hypothesis was that there is no significant relationship between participatory structure of the head teachers and student academic performance. From the study, the researcher established that there was a strong relationship between participatory traits of the head teachers and the management structures of the schools which has impact on the students' academic performance. The chi-square test in table 4.8 from the teachers' perspective attests to this finding as it shows high chi-square results, therefore null hypothesis was rejected.

This result also negates the findings of Drury and Levin (1994) which states that participatory management contributes to four intermediate outcomes which in turn have the potential to lead to better student achievement. The four outcomes are increased efficiency in use of resources and personnel, increased professionalism of teachers, implementation of curriculum reform and increased community engagement. Shared leadership is potentially more effective than head teachers acting alone. Staff is to achieve more together than they could as individuals (Seriovanni et al, 2001).

\subsection{School Resources}

The researcher carried a survey on courses and school activities that help in improving academic performances of students from both the head teachers and the teachers from the sampled respondents. The responses were in terms of whether the resources were Adequate, Not adequate or not available. The findings from both teachers and head teachers were as tabled below:

Table 4.10. Responses from the Teachers on School Facilities

\begin{tabular}{|l|c|c|c|}
\hline \multicolumn{1}{|c|}{ School Resource lactivity } & Adequate & Not adequate & Not Available \\
\hline Laboratory & 15 & 57 & - \\
\hline Library & 7 & 53 & 12 \\
\hline Guidance and counseling program & 9 & 48 & 15 \\
\hline Students commitment to school & 17 & 52 & 3 \\
\hline Head teachers' commitment to teaching & 26 & 42 & 4 \\
\hline Teaching and instructional materials & 28 & 39 & 5 \\
\hline $\begin{array}{l}\text { Head teacher's ability to work harmoniously with } \\
\text { teachers. }\end{array}$ & 33 & 35 & 4 \\
\hline Sports and Games & 28 & 39 & 5 \\
\hline
\end{tabular}

Table 4.11. Responses from the Head Teachers on School Facilities

\begin{tabular}{|l|c|c|c|}
\hline \multicolumn{1}{|c|}{ School Resource /activity } & Adequate & Not adequate & Not Available \\
\hline Laboratory & 3 & 3 & - \\
\hline Library & 2 & 2 & 2 \\
\hline Guidance and counseling program & - & 5 & 1 \\
\hline Students commitment to school & 2 & 3 & 1 \\
\hline Teachers' commitment to teaching & 4 & 2 & - \\
\hline
\end{tabular}




\begin{tabular}{|l|l|l|l|}
\hline Teaching and instructional materials & 3 & 3 & - \\
\hline Debating Club. & 1 & 2 & 3 \\
\hline Science Club & 3 & 1 & 2 \\
\hline Sports and Games & 3 & 3 & - \\
\hline
\end{tabular}

\subsection{Adequacy Measured on by Student Facility Ratio}

The researcher asked the teachers to give their opinion on whether there was a relationship between the leadership style and the student's academic performances in Kenya Certificate of Secondary Education, $93.1(n=67)$ said yes while 6.9\% $(n=5)$ of the respondents disagreed. The reasons were as in table 4.9.

Table 4.12. Responses from Teachers on Facility Ratio

\begin{tabular}{lcc}
\hline Adequacy on & Frequency & Percentage \\
\hline Head teacher motivates teachers & 33 & 46.2 \\
They create a conducive environment & 54 & 69.2 \\
They are role models & 26 & 36.0 \\
They source equipment, teaching staff and other facilities & 42 & 59.0 \\
Any Other & 2 & 2.6 \\
& & \\
\hline
\end{tabular}

Table 4.13. Responses from Head Teachers On Facility Ratio

\begin{tabular}{ll}
\hline Problems Encountered & Percentage \\
\hline Inadequate facilities & 66.7 \\
Inadequate Staff & 100.0 \\
Poor disbursement of F.D.S.F. & 33.0 \\
Uncooperative parents, guardians and teachers & 83.3 \\
Absenteeism both students and teachers & 100.0 \\
Undisciplined students & 50.0 \\
Others & - \\
\hline
\end{tabular}

\subsection{Suggested Solutions to the Problems Encountered}

The researcher asked the head teachers for their opinion on the solutions to problems they encounter in management of schools and they suggested the following solutions;

i. There should be proper guidance and counseling to guide students to attend classes throughout by checking regular class attendance and if possible expel indiscipline students

ii. Prompt fees payment by NGOs and other well-wishers, for the less fortunate students like orphans and more infrastructural funding through the CDF

iii. Occasionally head teachers should be encouraged to review leadership style and check effect on student performance, adequate staffing by the TSC, and in-servicing of teachers through workshops

iv. Co-operation from guardian/parents by holding regular meetings and working out strategic plans

v. Frequent inspection by Ministry of Education and Quality Assurance Officers

vi. Availability of adequate facilities

vii. Timely disbursement of government funding

viii. Organizing of academic days and parents teachers meet the students to motivated them.

ix. Transfer teachers say after three years of service in one school

\subsection{Recommendations}

The following were the suggested remarks from both teachers and head teachers relevant to enhance leadership in secondary schools for the betterment of both teachers and students. They included;

i. The publishing of booklets to disseminate information to the community on proper education management and examination improvement in order to remove ignorance on the part of the local community 
ii. The students and teachers to carry bench marking for better results

iii. A good academic performance requires teachers, students and workers motivation in terms of salaries and material support as free working condition makes performance to improve. Head teachers should co-operate to other teachers in day to day management of schools.

iv. The head teachers need to be sensitized on how to relate not only with the teachers but the entire community and be team players

v. Teachers should be allowed to evaluate and recommend the performance of head teachers

\section{Conclusions}

It is evident from the research findings that there is a lot of delinquency in leadership styles of the head teachers and their impact on the students' academic performance in secondary schools in Nyamaiya Division, Nyamira District. The researcher hypothesized that there is no significant relationship between initiative structure of the head teachers and the students' academic performance but the findings shows different responses from respondents. The findings shows a significant relationship between initiative structures of the head teachers towards improving leadership style which has impact on academic performance, therefore the null hypothesis was rejected.

In terms of consideration structures, the researcher hypothesized that there is no significant relationship between consideration structures of the head teachers and the student academic performance and the findings also shows no significant relationship between consideration behavior of the head teachers regarding day to day issues which has impact on academic performance as presented by low high chi-square results in table 4.6 therefore the null hypothesis was accepted.

Finally in terms of participatory management, the hypothesis was that there is no significant relationship between participatory structure of the head teachers and student academic performance. From the study, the researcher established that there was a strong relationship between participatory traits of the head teachers and the management structures of the schools which has impact on the students' academic performance. The chi-square test in table 4.8 from the teachers' perspective attests to this finding as it shows high chi-square results, therefore null hypothesis was rejected.

The study therefore, concludes that secondary schools in Nyamaiya Division have not succeeded in imparting proper leadership skills by the head teachers due to factors mentioned earlier. Now, it is therefore upon the government and other players in the education sector to take monitoring and evaluation seriously in order to address the possible leadership styles of the head teachers and their impact on the students' academic performance in secondary schools not only in Nyamaiya Division but other parts of the country.

\section{References}

Achola, P.P.W. (1990). The Influence of Selected Teacher Factors and School Practices In School Achievement. The Case of Semi-Arid Kajiado, Maasailand. Bureau Educational Seminar Paper, No. 20206, Kenyatta University.

Barrow, R. S. (1976). The Role of the Head teacher. Rutledge and Kegan Paul Ltd,London.

Bass, B. M. (1985). Leadership and Performance Beyond Expectations, New York, Free Press.

Beck, L.G., Murphy, J. (1996). The four imperatives of a successful school. Corwin Press.

Bell, L. and Rhodes, C. (1996), The Skills of Primary School Management, London: Routledge.

Blasé, J. (1995), The Micro-Politics of Educational Leadership from Control to Empowerment. London: Cassell.

Blase, J., and Blase, J. (2000). Effective instructional leadership: Teachers' perspectives on how principals promote teaching and learning in schools. Journal of Educational Administration, 38(2), 130-141.

Borg, R. W. and Gall M. D. (1989). Educational Research; An Introduction. New York; Longman Inc

Brewer. H. (2001). Ten Steps to Success. Journal of Staff Development. 22(1), 30-31

Burns, J. M. (1978), Leadership, New York; Harper Collins.

Campbell, R. F. (1974). Educational Management as a Social Process; Theory, Research and practice, New York, Harper and Row. CCEA, London

Coffey, A., B. Holbrook and P. Atkinson (1996). 'Qualitative Data Analysis: Technologies and Representations', Open University Press.

Cole, G. A. (1997). Management: Theory and Practice, Essex, Spotwood Balantune Ltd

Comparative Analysis in Comparative Educational Review, Vol. 27, No. 1

Coombs, H. P. (1970). What is Educational Planning, Paris: UNESCO.

Daily Nation, (2010, January 26. Pg 3), Nairobi. Nation Newspapers Ltd.

Dalin, P. (1994). How Schools Improve: An International Report. London, Cassell

Davies, B., Ellison, L., Bowring-Carr, C. (2005). School Leadership in the 21st Century: Developing a Strategic Approach. London: 
Routledge Falmer

Davis, S., Darling-Hammond, L., LaPointe, M., \& Meyerson, D. (2005). School Leadership Study: Developing Successful Principals (Review of Research). Stanford, CA: Stanford University, Stanford Educational leadership Institute.

DuFour, R. (May 2002). The learning-centered principal. Educational Leadership, 59 (8). 12-16

Dufour, R., Eaker, R. (2006). Learning by Doing: A handbook for Professional Learning Communities at Work. Bloomington, IN: Solution Tree.

Eshiwani, G. S. (1983). Factors Influencing Performance Among Primary and Secondary Schools in Western Province. Policy Study (Kenyatta University College). Bureau of Educational Research.

Fieldler, F. E. (1976). The Leadership Game: Matching the Man to the Situation: Organizational Dynamics

Foster, P and Clignet, R. (1966). The Fortunate Few: A study of Secondary Schools and Students in the ivory coast, Evanston Illinois, North-Western University Press.

Gay, L. R. (1992). Education Research: Competence for Analysis and Application 4th Edition, New York, Macmillan Publishers.

Gibbs, G R (2002). Qualitative Data Analysis: Explorations with NVivo. Buckingham: Open University Press.

Goldring, E., Cravens, X, Murphy, J., Elliott, S., Carson, B., \& Porter, A. (March 2008). The Appraisal of Principals: What and How Do States and Districts Assess Leadership. Paper presented at the annual meeting of the American Educational Research Association, New York, p. 20.

Goldring, E., Porter, A.C., Murphy, J., Elliott, S., Cravens, X. (March 2007). Assessing learning-centered leadership: Connections to research, professional standards, and current practices. Journal of Leadership and Policy in Schools.

Habegger, S. (September/October 2008). The principal's role in successful schools: creating a positive school culture. Educational Leadership, 88(1), 42-46.

Haji, M. Y. (1985)., A Report of Educational Standard of Western Province The cause of Declining Performances in National Examinations. Government Printers, Nairobi.

Hall, P.W. (2002). What principals need to know about teaching and learning. In The Principal Challenge: Leading and Managing Schools in an Era of Accountability. Tucker, Marc S. \& Codding, Judy B., eds. (2002) San Francisco, CA: Jossey-Bass.

Hallam, S. (1996), Improving School Attendance, Oxford Heinemann

Halpin, A. W. (1966). In Carver and Segiovanni (editors) Organizations and Human Behaviour. McGraw Hill Book Company, New York. Hargreaves, A, (2002). Changing Teachers, Changing Times: Teachers Work and Culture,the postmodern Age, London: cassell.

Heyneman, S, and Lexley, W. (1981). Influence on Academic achievement across High and Low Income Countries, Sociology of Education, Vol 55.

Heyneman, S. (1984). Research on Education in the developing countries. International Journal of Education Development. Vol 4 No 4

Hoy, K. W. and Miskeel, G. G. (1992). Educational Administration Theory, Research and practice. New York: Macmillan publishers.

Jenkins, B. (January/February2009). What it takes to be an instructional leader. Principal, 88(3) 34-37.

Kathuri, C. R (1985). Research Methodology; Methods and Techniques, New Delhi Willey.

Katuli, N. J. (1982). Factors that Influence the Performance of Pupils in CPE. Research Paper No. 1093, Bureau of Educational Research , Kenyatta University.

Katz, (1978). Job Longevity As A Situational Factor In Job Satisfaction In Administrative Science Quarterly.

Kenya Times, (May 19 2009). "Why Some Schools Have A Tradition of Excelling in Examinations

Kerlinger, F. N. (1973).Foundation of Behavioral Research, Administration Today Columbus Charles Merril Co. (2nd Edition)> Holt Rinlialt and Winston Inc New York.

Kibowen, P.C, (1985). Factors that Influence the Poor Performance of KCE (O 'Level') Examination) A case Study of North Baringo. M.A. University of Nairobi

Knapp, M., Copland, M.A., Ford, B., Markholt, A. (2003). Leading for Learning Sourcebook: Concepts and Examples. Center for the Study of Teaching and Policy, Dewitt Wallace-Reader's Digest Fund, and Lila Wallace-Reader's Digest Fund, 2003.

KNEC, (2004). KCSE Examination Analysis Report. Government Printers, Nairobi

Labaree, D. (1992). Power, Knowledge and Rationalization of Teaching: A Genealogy and Move to Professionalize Teaching, Harvard Educational Review 62(2)

Leithwood, K., Riehl, C. (January2003). What we Know About Successful School Leadership. Philadelphia, PA: Laboratory for Student Success.

Leithwood, K., Seashore-Louis, K., Anderson, S., \& Wahlstrom, K. (2004). How Leadership Influences student Learning (Learning From leadership Project Executive Summary). New York: The Wallace Foundation.

Magori, P. J. O. (1990., A Study of Factors That May Cause Poor Performance in KCPE in Busoga Division, Kisii District. Med Thesis, Kenyatta University

Malau, N. C. (1988., A Survey Into the Probable Causes of Poor Performance of Kilifi District, Coast Province. MED Project, Kenyatta University

Manu, P. (2007). Leading Without Tears, Maharashtra: Angela Enterprises.

Marzano, R. J., Waters, T., \& McNulty, B. A. (2005). School Leadership that Works: From Research to Results. Alexandria, VA: Association for Supervision and Curriculum Development.

Maundu, J. N. (1986). 'Student Achievement in Science and Mathematics: A case Study of Extra Provincial and Harambee Secondary Schools in Kenya. Unpublished PhD Dissertation Department of Secondary Education. McGill University, Montreal.

Mbithi, D. M. (1974). Foundations of School Administration. Oxford University Press, Nairobi. 
McGregor, D. (1960). The Human Side of Enterprise, NcGraw Hill, New York. Eastern Ltd.

Ministry of Education, (2002). Reform Agenda for Education Sector in Kenya; Setting Beacons for Policy and Legislative Framework, Nairobi: Government Printer.

Moore, B. (January/February2009). Improving the appraisal and feedback process for principals. Principal. 38-41.

Mugenda, O. M. (1999). Research Methods. Quantitative Approaches. Acts Press Nairobi.

Murphy, J. (1999). Reconnecting teaching and school administration: A call for a unified profession. UCEA Review, 40(2), 1-3, 6-7.

Murphy, J., Elliott, S.N., Goldring, E., and Porter, A.C. (2007a). Leadership for learning: a research-based model and taxonomy of behaviors. School Leadership and Management, Vol. 27, No. 2, pp.179-201.

Murphy, J., Elliott, S.N., Goldring, E., and Porter, A.C. (2007b). Leadership for Productive Schools. Unpublished manuscript.

Murphy, J., Elliott, S.N., Goldring, E.B., \& Cravens, X. (2007c). Measuring learning-centered leadership: A conceptual foundation. East China Normal University Journal/August 2007

Murphy, J., Elliott, S.N., Goldring, E.B., \& Porter, A.C. (2006). Learning-Centered Mutai, B.K. (2000. How to 'Write Quality Research Proposal, a Complete and Simplified Research, Thelley, New York.

Muya W. (1993). Educational Policy-Reform or Die. Sunday Nation, July 31, Science Teaching Vol. 16, No.1.

Mworia, R.N. (1993). Performance in KCPE-A Case Study of Central Imenti Division, in Meru District, MED Thesis Kenyatta University

Nalemo, S. P. (2002). Factors Influencing the Choice of Leadership Styles in Baringo Secondary Schools.

Nwana, M. (1982). Educational Research for Modern Scholars. Fourth Dimension, Emugu, Nigeria

Ogawa and Hart, (1985). The Effect of Principals on the Instructional of Performance of Schools. The Journal of Education Administration. Vol XXIII, No. 1

Olantunji, S. A. (1995). Inaugural Lecture Series 9. Progress Through Evaluation, University Press

Olembo, J. (1975). Head Teacher Training and Resource Materials Development in Africa. Paper Presented at the Asia Pacific Workshop on Head teacher Training and Resource Materials Development. University of Baroda: India.

Olembo J. O. Wanga P, E. and Karagu, N. M. (Eds,) (1992). Management in Education (1st Ed.) Nairobi. Educational Research and Publications (EARAP)

Orodho, A. J. (2004). Statistics Made User Friendly for Education and Social Science Research. Masola Publishers

Orodho, A.J. (1996.. Factors Determining Achievement in Science Subjects at Secondary School Level in Kenya. A PhD Thesis, Kenyatta University.

Orodho, A. J. (2003). Essential of Educational and Social Sciences Research Methods Masola Publishers

Portin, B.; Schneider, P.; DeArmond, M.; Gundlach, L (2003). Making Sense of Leading Schools: A study of the School Principalship. Seattle: Center on Reinventing Public Education.

Raju, B. M. (1973). Education in Kenya, Educational Books

Ramsey, R. D. (2005). Lead, Follow or Get Out of the Way (2nd Edition). United States: Corwin Press. Review. World Bank Washington DC. USA

Saha, L. J. (1983). Social Structure and Teacher Effect on Academic Achievement. A Comparative Analysis in Comparative Educational Review, Vol.27, No. 1

Seidel, J. \& Kelle, U. (1995) 'Different Functions of Coding in the Analysis of Textual Data' in U. Kelle (editor) Computer-Aided Qualitative Data Analysis: Theory, Methods and Practice. London: Sage.

Sergiovanni, et al (1987). The Principal Ship: A Reflective Practice Perspective. Boston: Allyn and Bacon Longwood Division.

Short, P. M., and J. T. Greer. 1997. School Leadership in Empowered Schools: Themes From Innovative Efforts. Upper Saddle River, N.J.: Simon \& Schuster.

Stewart, A. (1990). Social Stratification and Occupation, London, Macmillan

Stogdill, R. M. (1974). Handbook of Leadership. A Survey of the Literature, New York, Free Press.

Tetty-Enyo, (1997). Critical Issues in School Management. Paper Presented at the Teacher Management and Support. Anglophone and Francophone Seminar, CCEA, London.

Theisen, T. (1967). International Study of Achievement in Mathematics. A comparison Of Twelve Countries. John Willy and Sons.

Tirozzi, G. (2001). The Artistry of leadership: The Evolving Role of the Secondary Principal. Phi Delta Kappan, 82(6): 434-439.

Togneri, W., Anderson, S. (2003). Beyond Islands of Excellence: What Districts can do to Improve Instruction and Achievement in all Schools. Learning First Alliance.

Waithaka, J, M. (1987). Issues in Administration and Management of Educational Personnel Programmes, Republic of Kenya. Report of the Educational Administration Conference. Nairobi, Government Press.

Wallace Foundation.(March,2009). Assessing the Effectiveness of School Leaders: New Directions and New Processes. New York City. Accessed at http://www.wallacefoundation.org/KnowledgeCenter/KnowledgeTopics/CurrentAreasofFocus/EducationLeadership /Documents/Assessing-the-Effectiveness-of-School-Leaders.pdf

Welgemoed, A. (1995). Priorities and Strategies for Education. A world Bank Review. World Bank Washington DC. USA.

Yeya, M. S. (2002). An Investigation of the Probable Causes of Poor Performance in KCSE in Matuga Division, Kwale District, Coast Province.MED Project, Kenyatta University.

Zepeda, S.C. (2007). The Principal as Instructional Leader: a Handbook for Supervisors (second edition). Larchmont, NY: Eye On Education, Inc. 